\title{
The Present Limits and Future Potential of European Social
}

\section{Constitutionalism}

\section{Colm O'Cinneide*}

\section{Introduction: Broadening the Conversation}

Within Anglo-American constitutionalist thought, ${ }^{1}$ social rights are generally assumed to fall outside of the appropriate scope of constitutional regulation: their content and status are viewed as matters best left to be determined by the free flow of political contestation, rather than being governed by the written provisions of the constitutional text and/or judicial interpretation of fundamental rights guarantees. ${ }^{2}$ The development of socioeconomic rights review in states of the Global South such as South Africa, Colombia, India and Brazil challenges this assumption. As a result, the apparent dichotomy between the 'old' Anglo-American orthodoxy and the 'new' social constitutionalism emerging in the Global South has come to dominate much of the comparative constitutional literature on social rights.

However, as Hirschl has argued, comparative scholarship needs to be careful about restricting its focus to a few favoured national case studies. ${ }^{3}$ There exists an alternative strand of social constitutionalism in continental Europe, which is barely mentioned in much of the academic literature

\footnotetext{
* Professor of Constitutional and Human Rights Law, UCL; former member of the European Committee on Social Rights 2006-2016. All views expressed here are personal to the author.

${ }^{1}$ The term 'Anglo-American constitutionalism' is used here to refer to the manner in which legal and political actors in North America, the UK, and Australasia discuss, debate, and describe the purpose and functioning of their constitutional systems. These jurisdictions share a common legal and political tradition, and their constitutional traditions have similar intellectual roots.

${ }^{2}$ This is not to suggest that Anglo-American constitutional thought and practice adopts a uniform approach in this regard: see by way of contrast how a number of US state constitutions protect a range of social rights (see J. King, 'Two ironies about American exceptionalism over social rights' (2014) 12(3) Int J Const 572-602), and the manner in which UK administrative and human rights law extends a degree of indirect protection to such rights (C.O'Cinneide, 'Legal accountability and social justice', in P. Leyland and N. Bamforth (eds.) Accountability in Public Law (Oxford: OUP, 2013), 389-409). But, in general, Anglo-American constitutionalism adheres to the skeptical stance vis-à-vis the legal protection of social rights as set out above: see Colm O'Cinneide, 'The constitutionalisation of socio-economic rights', in Helena Alviar García, Karl Klare, and Lucy A. Williams (eds.) Socio-economic Rights in Theory and Practice: Critical Inquiries (Abingdon and New York: Routledge, 2014), pp. 258-276.

${ }^{3}$ Ran Hirschl, 'From comparative constitutional law to comparative constitutional studies' (2013) 11(1) International Journal of Constitutional Law 1-12, 8-9.
} 
on this topic. This 'European' strand of social constitutionalism differs in significant ways from the approaches to social rights protection being developed in the Global South. ${ }^{4}$ In some ways, it is weaker and more diffuse - at least when it comes to judicial enforcement of social rights. However, it has the potential to develop; and, in general, there are important perspectives to be derived from this European experience that need to be factored into the wider global debate about the future of social rights protection.

Part I of this paper outlines the development of social constitutionalism in Europe, at both the level of nation states and at the transnational level of the EU and the Council of Europe. Part II then explores how constitutional protection of social rights in Europe remains limited and uncertain in scope, despite the formal commitment of European states to what is described as the 'social state' principle. Part III analyses how the post-2008 austerity crisis has sharply exposed the normative inchoateness of European social constitutionalism, notwithstanding the gradual expansion in certain jurisdictions of judicial protection of social rights. Part IV examines how this crisis also opens up opportunities for legal protection of social rights to acquire more 'bite', with the concept of the 'social minimum' perhaps playing more of a role in this regard than in other legal systems. However, the argument is also made that the ultimate value of European social constitutionalism may be symbolic and political in nature, and lies in how it undercuts attempts to foreclose on the aspiration of creating a genuinely 'social Europe'. In conclusion, the tentative suggestion is made that the European experience may shed some light on the potential and limits of the social constitutionalist project at large.

\section{Part I - The Development of Social Constitutionalism in Europe}

Socio-economic rights are sometimes viewed as recent conceptual innovations, born out of the post1945 expansion of international human rights law. However, in continental Europe, the intellectual roots of social constitutionalism have a much older history, which can be traced back to the influence of the radical left element of the French republican movements of 1789 and 1848 with their

\footnotetext{
${ }^{4}$ Colm O'Cinneide, 'The Problematic of Social Rights - Uniformity and Diversity in the Development of Social Rights Review', in Liora Lazarus et al, Reasoning Rights: Comparative Judicial Engagement (Oxford: OUP, 2014), pp. 297-315.
} 
'integrated' concept of citizens' rights..$^{5}$ As early as 1793, the French National Convention adopted a constitutional text which acknowledged the right to work and to receive social assistance to be fundamental rights. ${ }^{6}$

More recently, this strand of constitutional thought found tangible expression in the Weimar Constitution of $1919^{7}$ and subsequently in the provisions of other continental European constitutions drawn up in the aftermath of the First and Second World Wars. The framers of these constitutions sought to add a social dimension to the classical liberal constitutional blueprint that had initially taken shape in the Anglo-American states before being transplanted into continental Europe in the second half of the $19^{\text {th }}$ century. This blueprint was structured around the concepts of rule of law and separation of powers, and lacked any substantive acknowledgement of the role increasingly being played by modern states in promoting social well-being. With the emergence of social democratic politics on the left, and social corporatist ideology on the right, this lack of a social dimension came increasingly to be viewed as a defect - which the framers of the post-war constitutions attempted to correct by inserting textual provisions that affirmed the necessity of state action to secure access to basic social goods. ${ }^{8}$

These 'social' provisions were designed to give symbolic expression to the national commitment to achieving social justice. They were also were intended to serve as reference points for the legislative and executive branches of government in exercising their powers, and to affirm the legitimacy of state action directed towards giving effect to social rights. ${ }^{9}$ However, they were not designed to generate subjective individual rights enforceable against the state by courts of law - reflecting both uncertainty as to whether such rights could be given direct effect in law, and also the general scepticism that

\footnotetext{
${ }^{5}$ George S. Katrougalos, 'The (dim) perspectives of the European social citizenship', Jean Monnet Working Paper 05/07 〈http://centers.law.nyu.edu/jeanmonnet/papers/07/070501.pdf〉 accessed 24 December 2013. ${ }^{6}$ Maximilien Robespierre, Textes Choisis (Paris: Editions Sociales, 1973), vol. II (August 1792-July 1793), p. 138. See also Title VIII of the Portuguese Constitutional Charter of 1826, and Article 13 of the short-lived French Constitution of 1848.

${ }^{7}$ See e.g. Articles 143, 151, 161 and 162 of the 1919 Weimar Constitution.

${ }^{8}$ As Thornhill puts it, these provisions were intended to ensure that 'formal rights under law... [were] flanked by rights of material dignity'. Chris Thornhill, A Sociology of Constitutions: Constitutions and State Legitimacy in Historical-Sociological Perspective (Cambridge: Cambridge University Press, 2011), p. 336.

${ }^{9}$ For a contemporary overview, see Franz Neumann, 'The social significance of the Basic Laws in the Weimar Constitution', originally published in German in Die Arbeit Jg. 7 Heft 9 (1930) 569-582, re-published and translated in (1981) 10(3) Economy and Society 329-347.
} 
existed across the European political spectrum at the time about the desirability of granting courts wide-ranging judicial review powers. ${ }^{10}$ Furthermore, from the beginning, the inclusion of these provisions in continental European constitutions was controversial. Many legal scholars viewed them as an exercise in empty rhetoric, or alternatively as an attempt by the political left to establish a legal platform justifying wholescale state interference with private property.

This hostile reaction had considerable effect. For example, in Germany, the unwillingness of conservative judges and the political parties of the right to give effect to the social rights provisions of the Weimar Constitution meant that they were 'robbed of any real legal [or political] substance' well before the Nazi takeover in $1933 .{ }^{11}$ However, the language of social constitutionalism nevertheless retained considerable political appeal, in particular because it gave expression to the values and aspirations of the social democratic left.

As a result, in the wake of the Second World War, when the post-war European constitutional orders were established on the basis of wide-ranging political compromises between right and left, extensive social provisions were written into the new constitutional texts of many Western Europe states. Similar provisions were subsequently included in the written constitutions of Southern and Central/Eastern Europe as they emerged from the Cold War era. As a consequence, the text of many European constitutions thus now expressly affirm that they are 'social states' (Sozialstaat in the German constitutional terminology), ${ }^{12}$ and/or contain lists of fundamental social rights or directive principles setting out social goals to which state policy should strive to give effect. ${ }^{13}$

The concept of the Sozialstaat came to be viewed as representing a constitutional affirmation of the concept of 'social citizenship' as famously outlined by T.H. Marshall, whereby the state is assumed to bear the responsibility of ensuring that its citizens enjoy the 'right to a modicum of economic welfare

\footnotetext{
${ }^{10}$ See in general Alec Stone-Sweet, 'The politics of constitutional review in France and Europe' (2007) 5(1) International Journal of Constitutional Law 69-92.

${ }^{11}$ Hans Mommsen, The Rise and Fall of Weimar Democracy (Chapel Hill: University of North Carolina Press, 1998), p. 60.

${ }^{12}$ See, for example, Constitution of Spain, art. 1(1); Constitution of Portugal, art. 2; Constitution of Slovenia, art. 2 .

${ }^{13}$ See, for example, Constitution of Belgium, art. 23; Constitution of the Netherlands, arts. 19, 20, and 22; Constitution of Greece, arts. 21 and 22; Constitution of Portugal, arts. 56, 59, 63-72, 108-9, 167, 216.
} 
and security' and 'to share to the full in the social heritage and to live the life of a civilized being according to the standards prevailing in the society [in question]' ${ }^{14}$ During this period, this conceptualisation of the state's role in securing social justice put down deep roots in European political culture - and it remains deeply embedded in its sub-soil, as evidenced by the continued European attachment to the concept of the welfare state. ${ }^{15}$

Thus, in Germany, the provisions of Article 20 of the Basic Law, which affirm that the transformed post-1945 polity is a Sozialstaat, have become an integral part of German constitutional selfidentity. ${ }^{16}$ In Katrougalos's words, this 'normative, prescriptive principle' is viewed as a fundamental organising norm of the German State, which is understood to be under an obligation both to act in accordance with the requirements of this principle and to take measures to give it concrete expression. ${ }^{17}$ A similar situation exists in many other continental European constitutional orders, with France, Belgium, Italy, Spain, Finland and Poland all being prominent examples. In general, some variant on the Sozialstaat principle is now acknowledged to be a background-structuring norm of most continental European constitutional systems, including those of the Central and Eastern European states which took shape after 1989. ${ }^{18}$ Even in the Scandinavian states, whose relatively minimalist constitutional texts do not contain much in the way of substantive 'social state' provisions, the idea that the state is committed to establishing and maintaining a comprehensive welfare state has

\footnotetext{
${ }^{14}$ Thomas Humphrey Marshall, Citizenship and Social Class (London: Pluto, 1992) (reprinted from his 1949 Cambridge Lectures), p. 8.

${ }^{15}$ To this day, Europe as a whole is often conceptualised as a 'social space' where the state takes an active role in ameliorating inequality and protecting individuals against the commodifying effects of the free market - in contrast to the more laissez-faire ethos of US social and economic policy, or the more utilitarian policies of emerging economies such as China. See for example the European Trade Union Confederation (ETUC)'s description of the 'European Social Model' on its website, https://www.etuc.org/european-social-model (accessed 2 October 2016).

${ }^{16}$ See in general Hans Michael Heinig, 'The political and the Basic Law's sozialstaat principle-Perspectives from constitutional law and theory' (2011) 12(11) German Law Journal 1879-1886.

${ }^{17}$ Katrougalos (n. 5) 9-15. See also Jeff King, 'Social rights, constitutionalism, and the German social state principle' (2014) 1(3) E-Pública: Revista Electrónica De Direito Público 19-40.

${ }^{18}$ Katrougalos, ibid; see also by the same author, 'The implementation of social rights in Europe' (1996) 292

Columbia Journal of European Law 277-312.
} 
become a core element of the framework of values that exert a dominant influence over their systems of constitutional governance. ${ }^{19}$

Furthermore, in line with this attachment to a distinctively European concept of social constitutionalism, virtually all Council of Europe states have signed and ratified the key UN and ILO instruments relating to socio-economic and labour rights - with most of these states taking pains to be in formal compliance with the reporting and monitoring requirements established under these treaties. Forty-three of the forty-seven Council of Europe member states have also ratified the European Social Charter (ESC), a treaty instrument which sets out a range of legal obligations relating to the enjoyment of core social and labour rights. ${ }^{20}$ In addition, fifteen of these states have signed up to the ground-breaking 'collective complaint' mechanism, a unique feature of the ESC system which permits certain categories of NGOs, employer and trade union organisations to bring a complaint to the body which monitors compliance with the Social Charter, the European Committee on Social Rights (ECSR), alleging that a ratifying state is not acting in conformity with its obligations under the Charter - thereby exposing themselves to a form of international review mechanism which has begun to generate an extensive and detailed case-law detailing the scope of state obligations under the ESC. $^{21}$

Furthermore, as EU law has developed, various attempts have been made to build a substantive social dimension into its supranational framework of binding legal norms which take direct effect within national law. Initially, EU law lacked such a social dimension - which has repeatedly attracted sharp criticism, driven by the concern that the absence of such a dimension would result in social protection at national level being undermined by the market integration requirements of EU law. ${ }^{22}$ However,

\footnotetext{
${ }^{19}$ Katrougalos, 'The implementation of social rights in Europe', 293-299. For discussion of the specific situation in Finland, see Kaarlo Tuori, 'Rights, democracy and local self-governance: Social rights in the constitution of Finland' (2007) 13 Juridica International 70-73.

${ }^{20}$ Colm O'Cinneide, 'The European social charter and EU labour law', in Alan Bogg, Cathryn Costello, and Anne Davies (eds.), Research Handbook on EU Labour Law (Elgar, 2016), pp. 191-213.

${ }^{21} \mathrm{Ibid}$. See also Holly Cullen, 'The collective complaints system of the European social charter: Interpretative methods of the European Committee on Social Rights' (2009) 9 Human Rights Law Review 61-93.

${ }^{22} \mathrm{See}$, for recent examples of this critique, Christian Joerges and Florian Rödl, 'On de-formalisation in European politics and formalism in European jurisprudence in response to the "social deficit" of the European integration project: Reflections after the judgments of the ECJ in Viking and Laval' (2008) 4(1) Hanse Law
} 
over time, some efforts have been made to fill this gap. The Preamble to the Treaty of European Union (TEU) now confirms the attachment of the EU member states to 'fundamental social rights', while Article 3(3) of the TEU proclaims that the EU shall work towards the establishment of a "highly competitive social market economy ... aiming at full employment and social progress', and promote 'social justice and protection'. Similarly, the EU Charter of Fundamental Rights, which since December 2009 has the same binding legal status as the EU treaties, contains an extensive list of social rights - such as the right to choose an occupation and engage in work (Article 15), the right to social security and social assistance (Article 34), the right to health care (Article 35) and a series of employment rights set out in Articles 27-32. In essence, these provision of the Charter are designed to give concrete shape to the EU's commitment set out in Article 3(3) TEU to respect the principles of 'social justice': all EU institutions and member states implementing EU law are required to respect the full range of rights set out in the Charter, as interpreted and applied by the Court of Justice of the EU (CJEU). ${ }^{23}$ Taken together with the aforementioned treaty provisions, the inclusion of these rights within the Charter represents an attempt to incorporate a social dimension into the framework of EU constitutionalism, reflecting similar developments at national levels.

\section{Part II - The Content and Limits of European Social Constitutionalism}

It is thus commonplace for the text of European constitutional instruments to contain provisions affirming the 'social state' principle and/or the commitment of the state to give effect to certain social rights. ${ }^{24}$ This reflects a wider tendency within European constitutional discourse to acknowledge the importance of the state's co-ordinating role in securing the enjoyment of basic social rights, and to incorporate this social dimension into conceptual discussions relating to the design and purpose of constitutional architecture in general - which stands in interesting contrast to Anglo-American

\footnotetext{
Review 3-22; also Floris de Witte, 'The architecture of the EU's social market economy', in Panos Koutrakos and Jukka Snell (eds.), Research Handbook on the EU's Internal Market (Edward Elgar, 2017), pp. 117-139. ${ }^{23}$ See in general Koen Lenaerts and Jose Antonio Gutierrez-Fons, 'The place of the charter in the EU constitutional edifice', in Steve Peers, Tamara Hervey, Jeff Kenner, and Angela Ward (eds.), The EU Charter of Fundamental Rights: A Commentary (Oxford, UK and Portland, Oregon: Hart, 2014), pp. 1559-1595.

${ }^{24}$ Cécile Fabre, 'Social rights in European constitutions', in Gráinne de Búrca and Bruno de Witte (eds.), Social Rights in Europe (Oxford University Press, 2005) pp. 15-31.
} 
orthodoxy in this regard.$^{25}$ Furthermore, it also reflects the existence of wide and continuing popular support for the welfare state among European electorates at large. ${ }^{26}$

The 'social state'/social rights provisions of European constitutions therefore play an important symbolic role: they affirm that the state is committed to maintaining a functioning welfare state in existence. They also perform a significant political function, by in effect serving as constitutional 'mission statements': they give expression to an established expectation that the legislative, executive and judicial branches of the state will exercise their powers and functions in a manner that respects the right of at least all citizens of the state to full 'social citizenship' ${ }^{27}$ Trade unions, civil society activists and other political groupings on the left are particularly quick to invoke the language of social constitutionalism to challenge cuts to existing welfare provision, even though this rhetoric does not always succeed in achieving its aims. ${ }^{28}$

Furthermore, the social rights provisions of European constitutions have in most states acquired a limited degree of legal substance. As Katrougalos has suggested, a 'European legal concept of social rights' has evolved in tandem with the construction of the welfare state, whereby courts and other key legal actors have come to acknowledge that the protection of social rights is part of the legitimate functions of the state. ${ }^{29}$ As a result, European courts are in general prepared to assume the inherent legitimacy of state action which is directed towards protecting social rights..$^{30}$ The social provisions of national constitutions are also often invoked by courts in concluding that state action that imposes constraints on the free market or private property rights is justified, generally as part of their reasoning

\footnotetext{
${ }^{25}$ King contrasts the well-developed theorising surrounding the concept of the Sozialstaat that exists in the German constitutional literature with the almost total absence of such theorising in the Anglo-American literature: see King, 'Social rights, constitutionalism, and the German social state principle', at n. 22 above. ${ }^{26}$ For example, at the time of writing in spring 2017, all the major political formations in the French and German legislative elections are committed to the maintenance of a comprehensive welfare state - including farright political parties such as the Front Nationale in France.

${ }^{27}$ See in general Ulrich K. Preuss, 'The concept of rights in the welfare state' in Gunther Teubner (ed.), Dilemmas of Law in the Welfare State (Berlin: Walter de Gruyter, 1986), pp. 151-172; Jürgen Habermas, 'Law as medium and law as institution', in Teubner, ibid., pp. 203-220.

${ }^{28}$ An interesting contrast exists in this regard to the United States, where calls for the federal government to reduce its commitment to social protection are often justified on the basis that this would represent a return to the 'original' or 'authentic' values underpinning the text of the US Constitution. This line of attack, regularly deployed in recent years by Tea Party activists, has little or no purchase in the European context: welfare state provision is clearly in conformity with the 'authentic' values of European constitutions.

${ }^{29}$ Katrougalos, 'The (dim) perspectives', at 4.

${ }^{30}$ George Katrougalos and Paul O'Connell, 'Fundamental social rights', in Mark Tushnet, Thomas Fleiner, and Cheryl Saunders (eds.), Routledge Handbook of Constitutional Law (Routledge, 2013), pp. 375-387.
} 
in support of the application of a 'light touch' standard of review to such measures. Primary and secondary legislation may also be interpreted by reference to the social dimension of the national constitutional order. ${ }^{31}$ In this way, these social rights provisions have often provided a constitutional basis for state action designed to establish and maintain the extensive post-war European welfare states. $^{32}$

In addition, in certain European states, the possibility exists that state action, which is manifestly incompatible with respect for social rights, may be overturned by the courts. ${ }^{33}$ Thus, in Germany, the courts have the authority to review a failure by the state to provide persons in need with an adequate level of social support that enables them to maintain a dignified existence and to participate in the social, cultural and political life of their society (known as the Existenzminimum). ${ }^{34}$ In some other European states, state action which restricts access to social support may be vulnerable to legal challenge if it rubs against the grain of fundamental constitutional principles such as equal treatment/rationality, human dignity or respect for the rule of law with its associated requirement of legal certainty, with the test of proportionality being applied to assess whether such measures can be shown to be objectively justified. ${ }^{35}$

The European Court of Human Rights has also held that states may in certain specific circumstances be required to provide certain basic forms of medical care and social assistance to individuals in need,

\footnotetext{
${ }^{31}$ For a sample of the French jurisprudence on this point, see Constitutional Council Decision No. 2010-617 DC, 9 November 2010. See also Laurent Pech, 'France: Rethinking "droits-créances"' in Malcolm Langford (ed.), Socio-Economic Rights Jurisprudence: Emerging Trends in Comparative Law (Cambridge University Press, ), p. 267-276.

${ }^{32}$ For an analysis of the role played by the Sozialstaat provisions of the German Basic Law in providing legal underpinning for the construction of the German post-war welfare state, see King, 'Social rights, constitutionalism, and the German social state principle'; see also Jutta Limbach, 'The role of the Federal Constitutional Court' (2000) 53 Southern Methodist University Law Review 429-442, 432 (the 'social State has also become one of the main pillars of civil law').

${ }^{33}$ See Katrougalos and O'Connell, n. 36 above.

${ }^{34}$ See Claudia Bittner, 'Human dignity as a matter of legislative consistency in an ideal world: The fundamental right to guarantee a subsistence minimum in the German Federal Constitutional Court's judgment of 9 February 2010' (2011) 12(11) German Law Journal 1941; Stefanie Egidy, 'The fundamental right to the guarantee of a subsistence minimum in the Hartz IV Case of the German Federal Constitutional Court' in same volume, 961. See also the following judgments of the Constitutional Court (BVerfG) and Federal Administrative Court (BVerwG): BVerfGE 125, 175 (Hartz IV, discussed below); BVerfGE 132, 135 (Asylum Seekers Benefits, discussed below); BVerfGE 1, 97 (104f); BVerwGE 1, 159 (161); BVerwGE 25, 23 (27); BVerfGE 40, 121 (133, 134); BVerfGE 45, 187 (229); BVerfGE 82, 60 (85) and BverfGE 99, 246 (259).

${ }^{35}$ See e.g. Wojciech Sadurski, 'Constitutional courts in the process of articulating constitutional rights in the post-communist states of Central and Eastern Europe part 1: Social and economic rights', EUI Working Paper Law No. 2002/14 <http://cadmus.eui.eu/handle/1814/192> accessed 10 September 2014.
} 
as an aspect of their overall obligations to respect core ECHR rights such as freedom from inhuman and degrading treatment, the right to life and the right to a fair trial. ${ }^{36}$ Similarly, EU legislation and national implementing measures which fail to respect the social rights provisions of the EU Charter of Fundamental Rights may in theory be disapplied by the CJEU. ${ }^{37}$

In other words, various 'apertures' exist in many European legal systems which make it possible for courts in certain circumstances to review the adequacy of state measures directed towards giving effect to the social state principle. Furthermore, European courts tend to be more willing to recognise that a clear demarcation line does not exist between socio-economic and civil and political rights: as the ECrtHR commented in Airey $v$ Ireland, 'the mere fact that an interpretation of the [civil and political rights protected by the ECHR] may extend into the sphere of social and economic rights should not be a decisive factor against such an interpretation; there is no water-tight division separating that sphere from the field covered by the Convention' ${ }^{38}$ Furthermore, the jurisprudence of the ECSR and the ILO expert bodies, and the interpretation they give to international social rights standards, exerts a certain degree of influence on the development of national law and policy in most European states - depending on the extent to which domestic legal and political actors are receptive to their findings.

However, in noting the significant functions performed by the 'social state'/social rights provisions of European constitutions, it is also important not to overstate their importance. European constitutionalism has a tangible social dimension, that can manifest itself in symbolic, political and legal forms. However, it remains 'thin', in the sense that it lacks much in the way of specific normative content: it can be difficult to identify exactly what public authorities should do to give effect to the social state principle, or what constitutes a breach of social rights. There is an expectation that governments will establish and maintain a relatively comprehensive welfare state in existence -

\footnotetext{
${ }^{36}$ See e.g. Airey v. Ireland (1980) 2 EHRR 305; MSS v. Greece and Belgium, Application no. 30696/09, Judgment of 21 January 2011; Tarakhel v. Switzerland, Application no. 29217/12, Judgment of 4 November 2014; Asiye Genç v. Turkey, Application No 24109/07, Judgment of 27 January 2015. See also Béláné Nagy v. Hungary, Application no. 53080/13, Judgment of 10 February 2015 - although note the convincing criticisms of this judgment by Ingrid Leijten at http://strasbourgobservers.com/2015/03/10/belane-nagy-v-hungary-a-selfstanding-right-to-obtain-social-benefits-under-the-echr/ (last accessed 1 May 2015).

${ }^{37}$ Case 176/12, AMS v. CGT, [2014] 2 CMLR 41.

38 (1980) 2 EHRR 305, (26).
} 
but, beyond this broad-brush commitment to the post-war status quo, the idea of the Sozialstaat lacks more precise definition.

As a consequence, the executive and legislative branches of government are assumed to bear the primary responsibility for putting flesh on the bones of the social state principle: as the elected organs of state, they are expected to define the scope and content of the social protection afforded by the national welfare state. National governments and parliaments are therefore given wide discretion in framing and giving effect to their socio-economic policies, and courts are generally reluctant to review their decisions. ${ }^{39}$ Thus, for example, Heinig notes that German legal scholarship 'has developed a canon on the [concept of the Sozialstaat], emphasizing in particular the limits of the constitutional principle' ${ }^{40}$ The political branches of the state enjoy wide discretion to determine what concrete content should be given to social rights and how forms of social provision should be financed.

Furthermore, the Sozialstaat principle is generally viewed as being insufficiently concrete by itself to generate subjective individual rights, in the sense of personal entitlements to receive specific forms of social assistance. This does not mean the concept of the social state lacks any legal effect: as noted above, it still constitutes an objective norm of the constitutional order which state action must respect. However, it limits the circumstances in which individual litigants can seek a legal remedy for a failure by the state to meet their socio-economic needs, even in states where government action is reviewable for compatibility with the Sozialstaat principle: the measure under attack must be shown to breach fundamental constitutional principles at the level of its design and overall impact, rather than by reference to the specific socio-economic situation of an individual litigant. ${ }^{41}$

\footnotetext{
${ }^{39}$ In certain states, social rights provisions are regarded as wholly non-justicable: see e.g. the directive principles contained in Article 45 of the 1937 Irish Constitution, as considered by the Irish Supreme Court in MhicMathúna v. Ireland [1995] IR 484.

${ }^{40}$ Heinig, n. 22 above, 1888-1890.

${ }^{41}$ This stands in interesting contrast to the 'reasonableness' approach adopted by the South African courts in socio-economic rights cases such as Government of South Africa v. Grootboom [2000] ZACC 19. In both South Africa and the European jurisdictions where social rights review is a possibility, courts focus on the overall justification of the measures under scrutiny rather than determining the subjective entitlements of individuals but in the South African cases, the specific situation of the individual litigants forms an integral part of the 'reasonableness' assessment.
} 
A similar approach is adopted in other states, and also at EU level - with the result that legal challenges to government measures restricting social protection will in general only succeed if (i) a measure is constitutionally objectionable in general terms, in the sense of breaching a core principle such as respect for human dignity or equality rather than infringing upon social rights/the social state principle as such; or (ii) its negative impact upon a particular individual can be framed as a breach of a 'subjective' civil and political right, such as the right to life.

Thus, for example, the social rights provisions of the EU Charter, such as the right to social security and social assistance set out in Article 34, are acknowledged to be 'principles' and not subjective individual 'rights' per se. ${ }^{42}$ As such, according to the explanations relating to the content of the Charter agreed by the Praesidium of the Convention which drafted the Charter in 2000, these provisions 'may be implemented through legislative or executive acts' of the EU institutions and Member States, but 'become significant for the [c]ourts only when such acts are interpreted or reviewed' and do not 'give rise to direct claims for positive action by the Union's institutions or Member States authorities'. ${ }^{43}$ Again, this does not mean that they lack all legal effect. A failure to respect principles of EU law may result in EU legislation or national implementing measures being overturned by the courts, while these principles may also be invoked by the CJEU and national courts in interpreting EU and national legislation. However, as at the national level, individuals cannot rely on these rights to show that their subjective entitlements have been denied. ${ }^{44}$ Instead, they have to make a case that measures affecting these rights are clearly incompatible with the relevant social principle at issue - which is a difficult hurdle to cross, as demonstrated by the fact that the CJEU has yet to find a breach of the social rights provisions of the EU Charter.

This lack of consensus as to the precise scope and content of social rights helps to reinforce the views of sceptics, who continue to regard the social rights provisions of European constitutions as little more

\footnotetext{
42 See generally Diamond Ashiagbor, 'Economic and social rights in the European Charter of Fundamental Rights' (2004) European Human Rights Law Review 63-72.

${ }^{43}$ Explanations Relating to the Charter of Fundamental Rights [2007] OJ C303/32 (prepared by the Praesidium of the drafting Convention).

${ }^{44}$ Jasper Krommendijk, 'After AMS: Remaining uncertainty about the role of the EU Charter's principles', EUtopia Law blog, 29 January 2014, available at https://eutopialaw.com/2014/01/29/after-ams-remaininguncertainty-about-the-role-of-the-eu-charters-principles/.
} 
than vague aspirations. It also limits their usefulness as constitutional 'mission statements', as it allows virtually all political actors to claim fidelity to some generalised notion of the 'social state'. It also means that findings by social rights monitoring bodies such as ECSR, ICESCR and the ILO expert bodies are often disregarded, with governments invoking the indeterminate nature of the rights at issue as a justification for their failure to respond to negative conclusions. ${ }^{45}$

The relationship between social rights provisions and other elements of the constitutional framework is also often ill-defined and uncertain, meaning that the social dimension to European constitutionalism is often required to take a backseat to more clearly delineated sets of norms. For example, the case-law of the CJEU has been subject to sustained criticism for appearing to give presumptive priority to free movement rights over the right to strike and other social rights. ${ }^{46}$

The social dimension to European constitutionalism is therefore lacking in normative substance, despite its prominence in the constitutional imaginary of Europe. ${ }^{47}$ In general, it imposes relatively few substantial constraints upon the exercise of state power. It forms an important part of the conceptual backdrop against which 'ordinary' constitutional law and politics plays out, but tends to lack definition - and, as a consequence, exerts at best a limited degree of influence over the main action on stage. This leaves room for other ideologies to acquire leading roles: ordo-liberalism with its emphasis on mobilising the state to create optimal socio-economic conditions for the operation of efficient markets has been historically at the forefront since the 1950s, but now is increasingly joined by its neo-liberal cousin. ${ }^{48}$

\footnotetext{
${ }^{45}$ See in general Judy Fudge, 'Constitutionalizing labour rights in Canada and Europe: Freedom of association, collective bargaining, and strikes' (2015) Current Legal Problems 1-39.

${ }^{46}$ Phil Syrpis and Tonia Novitz, 'Economic and social rights in conflict: Political and judicial approaches to their reconciliation' (2008) 33 European Law Review 411; Anne Davies, 'One step forward, two steps back? The Viking and Laval Cases in the ECJ' (2008) 37 Industrial Law Journal 126; Simon Deakin, 'The Lisbon Treaty, the Viking and Laval Judgments and the financial crisis: In search of new foundations for Europe's "social market economy"', in Niklas Bruun, Klaus Lorcher and Isabelle Schomann (eds.), The Lisbon Treaty and Social Europe (Oxford: Hart Publishing, 2012), pp. 19-45.

${ }^{47}$ For the concept of a 'constitutional imaginary', see Gerald Torres and Lani Guinier, 'The constitutional imaginary: Just stories about we the people' (2012) 71(4) Maryland Law Review 1052.

${ }^{48}$ For the often blurred distinction between ordo- and neo-liberalism, see Ralf Ptak, 'Neoliberalism in Germany: Revisiting the ordoliberal foundations of the social market economy', in Philip Mirowski and Dieter Plehwe, The Road From Mont Pèlerin: The Making of The Neoliberal Thought Collective (Cambridge, MA: Harvard University Press, 2009), pp. 98-138.
} 
Having said that, it is possible to see how European social constitutionalism might gradually acquire more tangible content, in both a political and legal sense. This could for example come about if courts extended the range of circumstances in which they were prepared to review state action restricting access to social protection, or if there was greater political and legal engagement at both national and EU level with international social rights standards.

In recent years, there are some signs that such a shift may be underway, driven in part by the austerity crisis that has gripped much of Europe since the economic crash of 2008. However, the manner in which this crisis has unfolded also serves to highlight the circumscribed and uncertain nature of European social constitutionalism in its present form. Austerity thus serve as a useful case-study, to illustrate both the current shape and future potential of the social dimension to European constitutional governance.

\section{Part III - European Social Constitutionalism under Pressure: The Impact of Austerity}

In discussing the ongoing European austerity crisis, some context may be useful. Over the last few decades, the comprehensive social safety-nets erected by the post-1945 development of the European welfare states have begun to fray at the margins, a process driven in part by the pressures of globalisation and budget control measures driven by the dominant ordo/neo-liberal ideology of the day. The economic crash of 2008 and the subsequent European debt crisis greatly accelerated this process. As noted by Hemerijck, the impact of these measures has been heterogeneous and uneven. ${ }^{49}$ But, in general, the ongoing 'era of austerity' has resulted in the erosion of welfare states across Europe - especially in the states of the Eurozone such as Greece, Spain and Portugal who have been required to make sweeping cuts to their systems of social security and labour market regulation. ${ }^{50}$

In response, various commentators have argued that austerity has exposed the existence of a serious disconnect between the grand rhetoric of European social constitutionalism and the increasingly threadbare reality of how social rights are protected in practice - with some going so far as to speak

\footnotetext{
${ }^{49}$ See generally Anton Hemerijck, Changing Welfare States (Oxford University Press, 2013).

${ }^{50}$ For a taste of these 'reforms', see Daniel Vaughan-Whitehead (ed.), Work Inequalities in the Crisis: Evidence from Europe (Geneva: ILO, 2012).
} 
about the 'hollowing-out' of the European social model, and by extension the commitment of states to the Sozialstaat principle. ${ }^{51}$

This is a partial exaggeration. ${ }^{52}$ To start with, social protection in European states remains much more extensive than in most parts of the world - even in states such as Ireland, Portugal and Spain which have had to implement wide-ranging austerity measures. ${ }^{53}$ Similarly, the social dimension to European constitutionalism still retains considerable 'bite'. At the symbolic and political level, it has regularly invoked by political opponents of austerity to challenge welfare cuts - who argue that any substantial dilution of the European social model represents a fundamental breach of the established social contract. At the legal level, the various 'apertures' that exist at national level which allow courts to review state action impacting on social protection have been used by litigants to challenge various austerity measures - and some of these challenges have resulted in significant victories.

Thus, for example, the German Constitutional Court concluded in 2010 that the manner in which the level of unemployment benefit had been fixed under the 2005 'Hartz IV' reforms to the German labour market had failed to adequately respect the principle of human dignity set out in Article 1 of the Basic Law, and required the German legislature to reconsider how living expenses should be assessed in recalculating the level of benefit to be paid out under this welfare programme. ${ }^{54}$ Similarly, the Court ruled in Asylum Seekers Benefits that the amount of cash benefit paid to asylum seekers awaiting processing of their claims was incompatible with the requirements of the human dignity principle, and again required the legislature to reconsider how the level of the benefits in question were calculated. ${ }^{55}$ Both judgments affirmed that the state is obliged to take positive steps to vindicate the social dimension of the human dignity principle, just as it is obliged to respect its more 'classical'

\footnotetext{
${ }^{51}$ See e.g. Agustín J. Menéndez, 'The crisis of law and the European crises: From the social and democratic Rechtsstaat to the consolidating state of (pseudo-)technocratic governance' (2016) 44(1) Journal of Law and Society 56-78. Menéndez goes on to suggest that the manner in which many austerity controls have been imposed on many states without going through the usual formal democratic processes of deliberation may also breach core rule of law norms.

${ }^{52}$ For further analysis, see Colm O'Cinneide, 'Austerity and the faded dream of a social Europe', in Aoife Nolan (ed.) Economic and Social Rights after the Global Financial Crisis (Cambridge: Cambridge University Press, 2014), pp. 169-201.

${ }^{53}$ Ibid.

${ }^{54}$ BVerfG, 1 BvL 1/09, 9.2.2010.

${ }^{55}$ BVerfG, 1 BvL 10/10, 18.7.2012.
} 
civil and political dimensions: more tangibly, the Constitutional Court clarified the factors the state had to take into account in fixing the level of the Existenzminimum, and demonstrated its readiness to review legislative measures which failed to comply with these requirements.

Other European courts have gone even further in reviewing austerity measures. In 2012 the Portuguese Constitutional Court ruled that the suspension of holiday bonuses paid to public employees and pensioners as part of an austerity budget was unconstitutional on the basis that it violated the right to equality, as only particular categories of person were affected by this measure and more equitable measures could have been adopted to achieve the same financial results. ${ }^{56}$ Subsequently, in April 2013, the Court again ruled that a range of emergency budget measures, including cuts to public-sector salaries and the imposition of a flat-rate solidarity tax, were incompatible with the principles of equal treatment/rationality and proportionality and a number of constitutionally protected social rights. ${ }^{57}$ Courts in Latvia, Italy, Rumania and a number of other jurisdictions have similarly been willing to review austerity measures for compliance with social constitutionalist principles, using proportionality analysis to assess whether the measures in question breached constitutional principles of equality, rationality and legal certainty ${ }^{58}$

If anything, austerity may be encouraging some national courts to intervene more readily in the socioeconomic domain, to shore up the constitutional commitment to the 'social state' principle. In this respect, it is significant that both Italian and Portuguese Constitutional Courts have emphasised that fundamental constitutional commitments - including the social state principle - cannot be sacrificed even in a situation of economic emergency. ${ }^{59}$

Furthermore, austerity has generated a wave of legal mobilisation around social rights issues which is unprecedented in Europe. This is reflected not only in the multiple legal challenges that have been

\footnotetext{
${ }^{56}$ Constitutional Court of Portugal, Judgment No 353/2012 (5 July 2012).

${ }^{57}$ Constitutional Court of Portugal, Judgment No 187/2013 (5 April 2013).

${ }^{58}$ See in general Claire Kilpatrick and Bruno De Witte (eds.), Social Rights in Times of Crisis in the Eurozone: The Role of Fundamental Rights Challenges, EUI Working Paper Law 2014/05; Xenophon Contiades and Alkmene Fotiadou, 'Social rights in the age of proportionality: Global economic crisis and constitutional litigation' (2012) 10(3) International Journal of Constitutional Law 660-668.

${ }^{59}$ See the papers by Tega, Lo Faro, Nogueira de Brito, Gomes and Cisotta and Gallo in Kilpatrick and De Witte (eds.), Social Rights in Times of Crisis in the Eurozone.
} 
launched at national level against cuts to social and labour protection, but also in the manner in which campaigning groups have frequently made use of international social rights mechanisms to challenge such cuts. For example, there has been a dramatic growth in the number of collective complaints submitted to the ECSR, with twice as many complaints referred to the Committee between 2008-2016 then had been referred in the decade before $2008 .{ }^{60}$ This has enabled the ECSR to deepen and develop its case-law, in the course of which it has repeatedly emphasised the need for state parties to the European Social Charter to respect social rights even in times of economic crisis and identified a range of austerity-linked measures which breach the minimum threshold requirements of the Charter including the automatic exclusion of long-term unemployed from welfare rolls in Bulgaria, ${ }^{61}$ the exclusion of particular categories of apprentices from the social security net in Greece, ${ }^{62}$ and a failure to maintain social support for older persons at an adequate level in Finland. ${ }^{63}$

However, it is also important not to overstate the significance of these legal developments. Throughout much of Europe, national courts remain reluctant to intervene in socio-economic matters, reflecting the orthodox view that the indeterminate nature of social rights means that the political branches enjoy wide discretion when it comes to defining their scope and substance. Within the context of austerity, this means that national courts have at times been very receptive to arguments that cuts to social protection were justified by the existence of a state of economic emergency - with the Greek courts, for example, being generally receptive to this line of argument. ${ }^{64}$

When courts have intervened, they have often attracted a degree of political backlash, varying according to the authority and status of the court in question. ${ }^{65}$ In Hungary, a hostile political reaction against a string of court judgments relating to social matters dating back to the 1990s resulted in the

\footnotetext{
${ }^{60}$ See the database of ECSR decisions in collective complaints, available at http://hudoc.esc.coe.int/eng\#.

${ }^{61}$ Complaint No. 48/2008, European Roma Rights Centre v. Bulgaria, Decision on the Merits of 31 March 2009.

${ }^{62}$ Complaint 66/2011, General federation of employees of the national electric power corporation (GENOPDEI) and Confederation of Greek Civil Servants' Trade Unions (ADEDY) v. Greece, Decision on the Merits of Decision of 23 May 2011.

${ }^{63}$ Complaint 88/2012, Finnish Society of Social Rights v. Finland, Decision on the Merits of 9 September 2014.

${ }^{64}$ Evangelia Psychogiopoulou, 'Welfare rights in crisis in Greece', in Kilpatrick and De Witte (eds.), Social Rights in Times of Crisis in the Eurozone, pp. 5-18, together with the other papers in that volume dealing with Greece.

${ }^{65}$ Kilpatrick and De Witte, ibid.
} 
constitution being amended so as to impose substantial constraints on the ability of the courts to intervene in the socio-economic realm. ${ }^{66}$ Nor is this reaction confined to the national level: state parties to the ESC have reacted at times with hostility to the ECSR's decisions in collective complaints and the national reporting process, and often fail to give effect to the Committee's conclusions. ${ }^{67}$ This again reflects the lack of any settled substantive core to European social constitutionalism, and the absence of a political consensus as to the appropriate role of courts and international social rights mechanisms in this context.

Furthermore, even where courts have intervened to strike down austerity measures, the ensuing caselaw is sometimes open to charges of inconsistency and partiality. This is particularly so in states such as Portugal and Italy where courts have applied wide-ranging proportionality review to overturn certain cuts to social security benefits and employment protection, while adopting a much more deferential stance in relation to other measures of a similar character. The Italian case-law in this regard has been described as giving rise to a "fluttering impression of a "random rationality" whereby the same legal arguments lead to different legal outcomes' ${ }^{68}$

Many of the national courts who have intervened in this context have shown a tendency to be more protective of established wage, pension and social security entitlements than other forms of social assistance. This is a by-product of the way in which constitutional principles such as equal treatment/rationality and legal certainty provide national courts with a firmer basis for proportionality review of austerity measures than the uncertain scope of the social state principle: courts are often more comfortable reviewing the proportionality of cuts to accumulated pension entitlements and other forms of contributory benefits available to relatively well-off groups such as public sector workers than they are reviewing the adequacy of other, more discretionary, forms of social and labour market protection. Again, the Italian case-law has been criticised on this basis: as Lo Faro has commented,

\footnotetext{
${ }^{66}$ See, for example, art. 17 of the Fourth Amendment (CDL-REF(2013)014) to the Fundamental Law of Hungary (CDL-REF(2013)016 - consolidated version), analysed by the European Commission for Democracy through Law (the 'Venice Commission') in its Opinion 720/2013, adopted on 17 June 2013, paras. 109-114.

${ }^{67}$ Fudge makes the point that a similar backlash has taken place with the ILO structures: Fudge, 'Constitutionalizing labour rights in Canada and Europe', at n. 51 above.

${ }^{68}$ Antonio Lo Faro, 'Fundamental rights challenges to Italian labour developments in the time of economic crisis: An overview', in Kilpatrick and De Witte (eds.), Social Rights in Times of Crisis in the Eurozone, 60-66, at 62 .
} 
'only ones who have been "saved" by the [Constitutional] Court are probably those who needed it least' ${ }^{69}$

The German jurisprudence is less vulnerable to these charges of inconsistency and double standards. Judgments such as Hartz IV set out a clear baseline of protection, which the state is obliged to provide to everyone living within its jurisdiction. However, this approach is narrower than the wide-ranging proportionality review applied by other national courts: the German Constitutional Court has made it clear that it will not in general police the adequacy of welfare benefits as long as the minimum level of social protection provided by the state conforms with the principle of human dignity. ${ }^{70}$ As Ingrid Leitjen has noted, the Court has thus effectively adopted what might be described as a "minimum core' approach to defining the socio-economic obligations of states - albeit one which sets the level of the Existenzminimum necessary to preserve human dignity at a considerably higher level than is common in states outside of Europe. ${ }^{71}$ The European Court of Human Rights could be viewed as having adopted a similar approach, albeit one that is inevitably constrained by the civil and political character of the rights it protects. $^{72}$

Thus, to summarise, the legal crystallisation at national level of European social constitutionalism remains embryonic. Courts have often adopted a highly deferential approach in this context, or applied proportionality analysis in a relatively unstructured manner, or else focused on defining the Hartz IV-style 'social minimum' that the state must provide to everyone in need but refrained from attempting to develop a wider-ranging social rights jurisprudence. Furthermore, the authority of international social rights mechanisms, even the ECSR with its well-developed case-law, remains contested.

\footnotetext{
${ }^{69} \mathrm{Ibid}, 62$. In this respect, there are interesting parallels with the arguments developed in David Landau and Rosalind Dixon, 'Constitutional Non-Transformation? Socioeconomic Rights beyond the Poor', in this volume. ${ }^{70}$ BVerfG, Order of the First Senate of 23 July 2014 - 1 BvL 10/12 - paras. (1-149), http://www.bverfg.de/e/ls20140723_1bv1001012en.html, BVerfGE 137, 34 - 103

${ }^{71}$ Ingrid Leitjen, 'The German right to an existenzminimum, human dignity, and the possibility of minimum core socioeconomic rights protection' (2015) 16(1) German Law Journal 23-48.

72 Ingrid Leitjen, 'Defining the scope of economic and social guarantees in the case law of the ECtHR', in Eva Brems and Janneke Gerards (eds.), Shaping Rights in the ECHR: The Role of the European Court of Human Rights in Determining the Scope of Human Rights (Cambridge: Cambridge University Press 2014), pp. 109-136.
} 
Austerity has thus exposed the relative 'thinness' of the social state principle, and of European social constitutionalism more generally. No clear consensus really exists as to what respect for this principle entails in practice. Particular disagreement exists as to the extent of social protection that a state should provide to its citizens, the degree to which respect for the 'European social model' should entail inter-state solidarity (as illustrated by the scale of the austerity measures inflicted on Greece and other Eurozone debtor states), and the scope of welfare support that should be provided to nonnationals resident within a state's borders.

Indeed, with the growth of hard anti-immigrant sentiment across Europe, this latter issue is increasingly coming to the fore - and it highlights a fundamental ambiguity lying at the heart of the social state principle. Is it a universalist human rights guarantee of adequate social protection to everyone living within a state's borders, or a particularist commitment to provide welfare support only to citizens of a state and others who have contributed appropriately to social insurance funds?

This unresolved tension is increasingly becoming an issue in case-law. The German Constitutional Court in its Asylum Seekers Benefits judgment has affirmed that it is not constitutionally permissible to 'differentiate among recipients of basic social benefits in accordance to their residence status; the legislature must always take as its guideline concrete needs to secure a person's existence'. Similarly, the ECSR has concluded that all state parties to the ESC must provide persons resident within their borders with a minimum level of social support. ${ }^{73}$ However, the ECSR's views in this regard have prompted a strong backlash from certain national governments, who argue that the Committee's reasoning constitutes an illegitimate extension of the logic of social rights. ${ }^{74}$ Given the background political climate and the budgetary constraints that austerity has already imposed on national welfare states, this issue is likely to become an increasingly serious point of political and legal fracture going forward - and it sharply illustrates the uncertain scope and content of the social state principle, and of European social constitutionalism more generally.

\footnotetext{
${ }^{73}$ See e.g. Collective Complaint No. 86/2012, European Federation of National Organisations working with the Homeless (FEANTSA) v. the Netherlands, Decision of 2 July 2014.

${ }^{74}$ See the response of the Netherlands government to the ECSR decision in Feantsa v. Netherlands: Appendix to Resolution CM/ResChS(2015)4 adopted by the Committee of Ministers of the Council of Europe on 15 April 2015 at the 1225 th meeting of the Ministers' Deputies, p. 6.
} 


\section{Part IV - The Way Forward}

The attempt to recognise and give substantive symbolic, political and legal form to a distinctively European concept of social constitutionalism thus remains at best an ongoing experiment. At best, European social constitutionalism provides a point of reference for political contestation, and a jumping-off point for the development of a circumscribed form of social rights jurisprudence. It also arguably helps to 'sensitise' legal systems to the existence of this necessary social dimension; and helps prevent 'constitutional silences' forming (to use Jeff King's term) ${ }^{75}$ whereby a failure to positively affirm what constitute the values of a constitutional system may enable courts and governments to smuggle in their own ideological preferences as to what those values should be. None of these achievements should be sneered at. But until social rights guarantees acquire greater normative substance, European social constitutionalism will remain stunted by a lack of definition.

This did not necessarily pose much of a problem when background economic and political factors favoured the expansion of the post-war welfare states - and the process of European integration broadly chimed with the values and aspirations underpinning the development of the 'European social model'. But the climate has changed. In his seminal book The Great Transformation published in $1944,{ }^{76}$ Polanyi analysed how forms of social protectionism such as strong labour unions and the structures of the welfare state were emerging in Europe to counteract the unhealthy dominance previously exercised by the market economy over society at large: but now markets seem to have largely cut loose from social control, while remaining forms of welfare support are increasingly denied to 'outsiders'. This has seriously exposed the thinness of European social constitutionalism at both the national and supranational level, even as nostalgia for the golden era of the post-war European welfare states grows and grows. ${ }^{77}$ (In this sense, the 'loss of social rights' that many

\footnotetext{
${ }^{75}$ Jeff King, 'Constitutions as mission statements', in Denis J. Galligan and Mila Versteeg (eds.), Social and Political Foundations of Constitutions (Cambridge: CUP, 2013) pp. 73-103 at 93-94.

${ }^{76}$ Karl Polanyi, The Great Transformation (London: Farrar \& Rinehart, 1944).

${ }^{77}$ Somek suggests that the value of the Sozialstaat principle has only become apparent as the erosion of social protection in Europe has reached a critical point: see Alexander Somek, 'Antidiscrimination and decommodification', University of Iowa College of Law Legal Studies Research Paper, 2005, available online at http://papers.ssrn.com/sol3/papers.cfm?abstract_id=651441.
} 
Europeans have experienced in the wake of the austerity crisis is best understood as a revelation that their 'rights' in this regard were never guaranteed in the first place.)

Having said that, it is clear that European social constitutionalism has the potential to evolve into something more tangible. The European states remain signed up to international social rights instruments, the text of their national constitutions affirm their commitment to the social state principle, and legal precedent exists that could provide a platform for the development of a more substantive social dimension.

In fact, some commentators have argued that all the necessary legal ingredients already exist for European courts to assume a wide-ranging role in securing compliance with the social state principle. They suggest that the proportionality test that is already an integral part of judicial review in Europe can simply be extended to cover all state action that interferes with social rights. ${ }^{78}$ As discussed above, a variant on this approach is ready being applied in Portugal and a number of other jurisdictions, and some of its proponents argue it could function as a European equivalent to the South African reasonableness approach. ${ }^{79}$

However, there are two problems with this argument. First, it is not clear how such a proportionality analysis would function. European welfare states are complex organisms: if courts are going to tinker with their functioning, it is essential that they are guided by a defensible and internally consistent set of norms. But, as Bilchitz has argued, 'proportionality cannot conceptually provide content to rights and, rather, requires... supplementation by a doctrine of content' ${ }^{80}$ Without such a doctrine specifying the scope and content of social rights, or at least the outline of such a doctrine, there is a risk that extending the scope of proportionality review to cover the full spectrum of state action which affects the enjoyment of social rights may generate seriously inconsistent or incoherent case-law - and thus

\footnotetext{
${ }^{78}$ See e.g. Xenophon Contiades and Alkmene Fotiadou, 'Social rights in the age of proportionality: Global economic crisis and constitutional litigation' (2012) 10(3) International Journal of Constitutional Law 660-668. ${ }^{79}$ Ibid.

${ }^{80}$ David Bilchitz, 'Socio-economic rights, economic crisis, and legal doctrine' (2014) 12(3) International Journal of Constitutional Law 710-739. Contiades and Fotiadou in replying to Bilchitz's argument have argued that the use of proportionality analysis by the Italian and Portuguese courts amongst others during the austerity crisis has shown that no such 'doctrine of content' is required to generate a coherent and substantive case-law: Xenophon Contiades and Alkmene Fotiadou, 'A reply to David Bilchitz' (2014) 12(3) International Journal of Constitutional Law 740-746. As will be apparent from this paper, I do not share their unqualified enthusiasm for this case-law.
} 
disrupt the existing political and administrative mechanisms for regulating systems of social protection without necessarily securing better practical protection of social rights. ${ }^{81}$ Furthermore, if respect for social rights is to be balanced against other competing state interests as part of a proportionality assessment, there is a real concern that they will be inevitably outweighed in the absence of a normative framework that assigns them appropriate mass and value - as demonstrated by the CJEU's case-law, where (as discussed above) the EU freedom movement rights of companies have in certain circumstances trumped the right to strike of trade unions. ${ }^{82}$

Furthermore, the legitimacy of courts making use of wide-ranging proportionality view to protect social rights would also be open to question. Such a step would entail a considerable extension of the existing constitutional role of European judges. In certain states such as Portugal, particular historic and legal factors have combined together to ensure that the courts have a relatively well-established mandate to review state action which impacts upon certain specified social rights. ${ }^{83}$ However, how such review should be conducted remains a matter of some dispute - and, in many other states, no such clear mandate exists. As a consequence, in the absence of a clear constitutional basis for courts to apply wide-ranging proportionality review, there is a risk in courts assuming such function. This could generate the type of political backlash discussed above - or, alternatively, the courts might choose not to risk such a backlash, and retreat instead into a deferential posture, thereby locking the legal dimension to European social constitutionalism into its current embryonic, under-developed state. $^{84}$

\footnotetext{
${ }^{81}$ For general discussion of this point, see Jeff King, Judging Social Rights (Oxford: Oxford University Press, 2012).

${ }^{82}$ See in particular Case C-341/05, Laval, [2007] ECR I-11767.

${ }^{83}$ See the papers by Nogueira de Brito and Gomes in Kilpatrick and De Witte (eds.), Social Rights in Times of Crisis in the Eurozone.

${ }^{84}$ Oliver Gerstenberg has suggested that European courts can play a 'democratic experimentalist' role in promoting social solidarity via the use of innovative methods of judicial review: Oliver Gerstenberg, 'The justiciability of socioeconomic rights, European solidarity, and the role of the Court of Justice of the EU' (2014) 33(1) Yearbook of European Law 245-276. I am sympathetic to this argument, which has echoes of the 'catalytic' approach advocated by Katie Young: 'A typology of economic and social rights adjudication: Exploring the catalytic function of judicial review' (2010) 8(3) International Journal of Constitutional Law 385420. However, in the European context at least, such an approach may struggle to acquire any real 'bite' unless it can again refer back to some substantive account of what the state should be doing to comply with its social commitments - which is currently lacking.
} 
There is an alternative track along which the legal protection of social rights could develop in Europe. The limited legal protection that currently exists at both national and pan-European level could be expanded incrementally, via a process of logical extension from established legal norms - as has happened to some extent during the austerity crisis. For example, the German jurisprudence on the 'social minimum' offers room for further growth, ${ }^{85}$ as do the ECHR judgments which acknowledge the existence of a social dimension to classical civil and political rights such as the right to life. Similarly, national case-law relating to the application of well-established constitutional norms such as the right to non-discrimination or the principle of legal certainty can be readily extended to 'social' contexts, if due care is taken in framing the relevant legal analysis.

In other words, existing legal doctrines could provide a foothold for the development of a more extensive social rights jurisprudence. ${ }^{86}$ Furthermore, any such development will be evolving with the grain of existing law, and emerging by extension from contexts where the judicial power to defend rights is well established. As a result, the inevitable legitimacy issues that will be generated by any such expanded jurisprudence may be eased - and will certainly be less problematic than those generated by a 'big bang' extension of proportionality analysis to encompass all state action interfering with the enjoyment of social rights.

Some commentators have been sceptical about whether such a 'stretching' of existing jurisprudence can generate a meaningful level of legal protection for social rights. In particular, doubt has been expressed about the concept of the 'social minimum'. Sceptics tend to equate it with the problematic concept of the 'minimum core' that exists within the ICESCR framework, and take the view that any such threshold requirement risks being interpreted as a right to 'bare subsistence' rather than as a substantive entitlement to meaningful levels of social support. However, this scepticism can be overstated. The social state principle has always envisaged that individuals should enjoy a 'baseline' level of secured access to a range of prized public goods such as affordable health care, adequate

\footnotetext{
${ }^{85}$ For the concept of 'incremental' development in this context, see King, Judging Social Rights.

${ }^{86}$ For example, the approach taken by the Court in Hartz IV in defining how the legislature should determine the level of unemployment benefit necessary to enable individuals to participate with dignity in society could hypothetically (with suitable modifications) be carried over into other contexts such as access to housing, health care, education and so on.
} 
social security and access to primary, secondary and tertiary education. Furthermore, this baseline is supposed to be pitched at an adequate level to enable participation with dignity in social, economic and cultural life, as acknowledged by the German Constitutional Court in Hartz IV. States often fail to respect this basic standard: however, in principle at least, this aspiration remains core to European social constitutionalism. Moreover, the content of this 'social minimum' can often be derived from the various statutory and administrative guidelines that regulate social provision within the existing framework of the European welfare states. Such guidelines tend to specify the baseline levels of forms of social support that should in theory be provided to citizens in need: they therefore provide a point of comparison for courts deciding the sufficiency and legitimacy of specific measures limiting or denying social support to particular individuals or groups - including irregular migrants and other groups excluded from the welfare safety net. ${ }^{87}$

As such, it should be possible in the European context to identify the content of a meaningful 'social minimum' that individuals are entitled to as of right, and for courts to enforce compliance with this norm through strong or weak methods of review or some combination of the two - as demonstrated by the German Constitutional Court's approach in Hartz IV and Asylum Seeker Benefits. Furthermore, if other constitutional principles are added into the mix, such as the right to equality and nondiscrimination, you arguably have sufficient raw ingredients to mix up a genuinely substantive European social rights jurisprudence ${ }^{88}$ Significantly, the jurisprudence of the ECSR is for the most part built around such a 'social minimum plus' approach - albeit with the important qualification that

\footnotetext{
${ }^{87}$ An analogy could be drawn here to the approach adopted by the Colombian courts: see David Landau, 'The promise of a minimum core approach: The Colombian model for judicial review of austerity measures', in Nolan (ed), (ed.) Economic and Social Rights after the Global Financial Crisis, pp. 267-298.

${ }^{88}$ Note that proportionality analysis could be used to assess the legitimacy of state action that impacts upon secured access to the 'social minimum', or otherwise cuts across existing substantive norms relating to the enjoyment of social rights more generally. The concerns expressed above about extending proportionality analysis to cover the full spectrum of social rights relate to the possibility of such an extension proceeding without a tangible account of the substantive content of such rights. Such content would however be provided by a developed concept of the 'social minimum', supplemented by equality and other existing norms - which, by defining the nature of the core rights at stake, would arguably give much greater analytical clarity to the application of proportionality review in the social context.
} 
state parties regularly grumble that the Committee sets the bar of this social minimum at too high and demanding a level. ${ }^{89}$

Having said that, two important qualifications have to be entered here, which should temper expectations about the future development of legal protection of social rights in Europe. First of all, high levels of complacency exist as to the adequacy of the European social model. This needs to be challenged before serious building work can begin on laying the foundations for a substantive mode of social constitutionalism. Secondly, any such European social rights jurisprudence - irrespective of the precise nature of its substantive and/or procedural content - will inevitably struggle to displace conventional assumptions about separation of powers and the indeterminate nature of social rights in general.

As a result, any legal mode of European social rights protection may end being orientated towards identifying the 'worst acceptable governmental practice' that will pass muster, as often happens in other areas of constitutional rights review - and this will impose inevitable constraints upon its transformative potential..$^{90}$ The jurisprudence of international social rights bodies such as the ECSR, the CESCR and the ILO expert committees bodies may help over time to expand the scope and content of such jurisprudence, by highlighting the limits of the status quo and outlining ways in which the relatively constrained type of social rights jurisprudence outlined here could develop in the future. However, presuming the political, social and economic structures of European life do not radically alter in the near future, their influence is likely to remain relatively limited. As a result, expanding the legal protection of social rights in Europe may help to patch some of the gaping holes that have opened up in welfare safety nets: however, beyond that, its impact may end up being very limited.

However, it is important to remember that the substance of social rights norms is capable of being articulated in different ways. The legal language of rights and constitutional controls cannot give

\footnotetext{
${ }^{89}$ See O'Cinneide, 'Austerity and the faded dream of a social Europe'. In general, the concepts of 'progressive realisation' and 'non-regression' play a less significant role in the jurisprudence of the ECSR than the CESCR, in part because of how the ECSR makes use of the social minimum approach (which alternatively might be described as setting 'advanced baseline' standards) to put flesh on the bones of the rights protected by the ESC. ${ }^{90}$ See Johan van der Walt, 'Delegitimation by constitution? Liberal democratic experimentalism and the question of socioeconomic rights' (2015) 3 Critical Quarterly on Legislation and Law 303-333.
} 
comprehensive expression to concepts of social justice, and should not be expected to do so. ${ }^{91}$ However, the symbolic and political dimensions to European social constitutionalism provide an alternative means of talking about social rights. For all of their vagueness, they give expression to the conceptual underpinning of the European social model - and therefore provide social movements with a point of critique to challenge government action that undermines that model. More importantly, by continuing to hold out the promise of a better Europe, they serve as an uncomfortable reminder of how Europe is currently falling seriously short of its ideals at both a national and supranational level. And this, in the final analysis, may be the ultimate purpose and function of European social constitutionalism in general - namely to warn against any premature foreclosing on the dream of constructing and maintaining a meaningful 'social state'.${ }^{92}$

\section{Conclusion: A Brief Comparative Perspective on European Social Constitutionalism}

There are specific aspects of the European experience of social constitutionalism that may differ from experiences elsewhere. Unlike in states such as South Africa, Colombia and India, attempts to give a legal dimension to social rights in Europe are not going hand-in-hand with fumbling attempts to erect the beginnings of a welfare safety net. Instead, the turn to the law in Europe has been partially in response to the erosion of once firmly established welfare states, whose initial construction proceeded hand-in-hand with the development of social constitutionalism rather than postdating it. Furthermore, the development of European social rights discourse plays out against the context of societies which remain relatively wealthy for now, and enjoy a high degree of social integration: as a consequence, the social rights debate in Europe is usually focused on how and whether to include marginalised groups within a generally established set of norms, rather than how to establish that general norm in the first place (as is often the case in the Global South).

\footnotetext{
${ }^{91}$ See J. King, 'The Future of Social Rights', in this volume.

92 Emilios Christodoulidis argues that social constitutionalism has an 'antinomic significance' which injects 'productive tension' into contemporary constitutional discourse, not least because it disturbs 'attempts to accommodate the continuity of civil, political, and social rights in the face of the contradictory articulation of social democracy and capitalism'. Emilios Christodoulidis, 'Social rights constitutionalism: An antagonistic endorsement' (2017) 44(1) Journal of Law \& Society 123-149.
} 
These differences may explain certain features of European social constitutionalism that may contrast with developments elsewhere. For example, they help to explain why the concept of a 'social minimum' might be more useful in constructing a substantive social rights jurisprudence in Europe than elsewhere: such a floor of rights protection already partially exists at national level, and can be 'stretched' by judicial rulings rather than having to be constructed from conceptual first principles.

However, there are also lessons of general applicability that can perhaps be carried over from the European context. First of all, positive constitutional rhetoric about social rights may not translate into much in the way of tangible legal protection - even if it can play a modest role in sensitising courts and other key actors to the importance of the social dimensions of the role of the state. Secondly, it may be necessary to focus more on defining the scope and content of social rights if proportionality/reasonableness analysis is to have much bite in this context. Thirdly, and finally, its major impact may ultimately lie in the symbolic and political realms, as a call to arms and a marker of aspirations, rather than as a legal tool for repairing holes in the welfare safety net. 